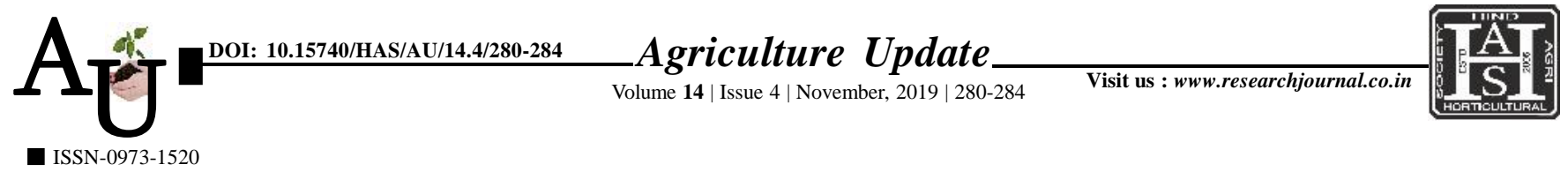

\title{
Rевевсн автіск: Documentation of existing cultivation practices followed by Khurasani (Guizotia abysinica spp.) growers of Palghar district of Maharashtra
}

\author{
Rohit Shelar, D. P. Hardikar, Himadri Roy and Shivananda P. Yarazari
}

Article Chronicle : Received :

19.09.2019;

Revised :

04.10.2019;

Accepted :

11.10.2019

KEY Words:

Cultivation practices, Khurasani growers, Oilseed crop

SUMMARY : Khurasani is an important secondary oilseed crop traditionally cultivated by tribal farmers from hilly area of Palghar district of Maharashtra. The genus Guizotia consists of six species, of which five, including Khurasani, are native to the Ethiopian highlands. In India it is considered as minor oilseed crop but it is very important in terms of its oil content, quality and potentiality. Practices followed by Khurasani growers have not been systematically documented so far. So, the present investigation was conducted in Jawhar and Mokhada tahsils of Palghar district with an objective, to document the existing cultivation practices followed by Khurasani growers. The sample was constituted 150 Khurasani growers drawn from two tahsils. The respondents were interviewed with the help of a semi-structured interview schedule. In this paper, analysis of data reveals on going practices followed by Khurasani farmers.

How to cite this article : Shelar, Rohit, Hardikar, D.P., Roy, Himadri and Yarazari, Shivananda P. (2019). Documentation of existing cultivation practices followed by Khurasani (Guizotia abysinica spp.) growers of Palghar district of Maharashtra. Agric. Update, 14(4): 280-284; DOI : 10.15740/HAS/AU/14.4/280-284. Copyright@ 2019: Hind Agri-Horticultural Society.

Author for correspondence :

\section{Rohit Shelar}

Department of

Extension Education,

Banaras Hindu

University, Varanasi

(U.P.) India

Email: rsagrico@gmail.

com

See end of the article for authors' affiliations 